NBER WORKING PAPER SERIES

\title{
RIESTER PENSIONS IN GERMANY: \\ DESIGN, DYNAMICS, TARGETTING SUCCESS AND CROWDING-IN
}

Axel H. Börsch-Supan

Michela Coppola

Anette Reil-Held

Working Paper 18014

http://www.nber.org/papers/w18014

\author{
NATIONAL BUREAU OF ECONOMIC RESEARCH \\ 1050 Massachusetts Avenue \\ Cambridge, MA 02138 \\ April 2012
}

This paper was prepared for a World Bank Workshop on Matching Defined Contribution Schemes in Washington, D.C., June 2010. We are grateful for comments by Frank Eich, Robert Holzmann, Richard Hinz, and David Tuesta Cardenas, and for financial support by the Research Institute for Policies on Pension and Aging (RIPPA) and the German Science Foundation (DFG) which has generously financed the creation of the SAVE panel data set and research based on these data. The views expressed herein are those of the authors and do not necessarily reflect the views of the National Bureau of Economic Research.

NBER working papers are circulated for discussion and comment purposes. They have not been peerreviewed or been subject to the review by the NBER Board of Directors that accompanies official NBER publications.

(C) 2012 by Axel H. Börsch-Supan, Michela Coppola, and Anette Reil-Held. All rights reserved. Short sections of text, not to exceed two paragraphs, may be quoted without explicit permission provided that full credit, including (C) notice, is given to the source. 
Riester Pensions in Germany: Design, Dynamics, Targetting Success and Crowding-In Axel H. Börsch-Supan, Michela Coppola, and Anette Reil-Held

NBER Working Paper No. 18014

April 2012

JEL No. D14,D91,H31,H55

\begin{abstract}
Riester pensions are voluntary, but heavily subsidized private pension schemes in Germany. They were designed as a matching defined contribution scheme to fill the emerging "pension gap" that is being generated by the gradually declining generosity of the public pay-as-you-go pensions in response to population aging. This paper investigates how the uptake of the recently introduced "Riester pensions" depends on the state-provided saving incentives and how well the targeting to families and low-income households has worked in practice. It documents the costs of the scheme, and collects circumstantial evidence on displacement effects between saving for old-age provision and other purposes.
\end{abstract}

After a slow start and several design changes, Riester pension plans took off very quickly. While saving incentives were effective in reaching parents, they were somewhat less successful in attracting low-income earners, although Riester pensions exhibit a more equal pattern by income than occupational pensions and unsubsidized private pension plans. Riester pension savings totaled $€ 9.4 \mathrm{bn}$ in 2010 with an associated cost of $€ 3.5 \mathrm{bn}$. One average one Euro of subsidies is thus associated with 2 Euros of households' own Riester saving.

There is no evidence that Riester pensions have crowded out other saving. While households who plan to purchase housing and who attach high importance to a bequest motive are less likely to have a Riester pension, several regression results show that occupational pensions and other forms of private pensions act as complements rather than as substitutes. Aggregate national saving has increased since the introduction of Riester pensions.

Axel H. Börsch-Supan

Munich Center for the Economics of Aging

Max Planck Institute

for Social Law and Social Policy

Amalienstrasse 33

80779 Munich

Germany

and NBER

axel@boersch-supan.de

Michela Coppola

Munich Center for the Economics of Aging

Max Planck Institute

पfor Social Law and Social Policy

Amalienstrasse 33

80779 Munich

Germany

coppola@mea.mpisoc.mpg.de
Anette Reil-Held

Munich Center for the Economics of Aging

Max-Planck-Institute

mfor Social Law and Social Policy

Amalienstrasse 33

80799 Munich

Germany

reil-held@arcor.de 


\section{Introduction: pension policy background and objectives}

Demographic change poses major problems for public pay-as-you-go pension schemes around the world, forcing many to reduce their generosity. In Germany, this took place in several steps, starting in 1992 with an indexation of benefits to net rather than gross earnings and the introduction of semi-actuarial adjustments in case of early retirement, and later with the introduction of the sustainability factor in 2004 that indexes benefits to the inverse of the system dependency ratio (i.e., the ratio of contributors to beneficiaries). It is estimated that in 2040, the benefit-to-earnings ratio will on average be about 18 percentage lower than in 2010 .

These reforms will result in a large and potentially increasing gap in old-age income relative to the current benefit levels. Recognizing this, the German, and many other governments, have accompanied public pension reform with efforts to strengthen funded second pillar (occupational) and third pillar (private savings) pensions. In order to accelerate the uptake of such private pensions, two competing strategies have been applied: making such supplementary pensions mandatory (e.g. Sweden and the Netherlands) or heavily subsidizing savings for private pensions, typically by matching contributions, providing tax credits, and/or permitting contributions to supplementary pension to be excluded when calculating income for tax purposes. Germany has taken the latter incentive-oriented approach with its so-called Riester pensions (named after Walter Riester, former German Secretary of Labor and Social Security) that were legislated as part of the 2001 pension reform. ${ }^{1}$

Riester pensions are effectively state-subsidized voluntary individual saving arrangements with an associated (largely annuitized) payout plan. They are designed to enable all individuals receiving a public pension or a similar state-provided benefit to fill the emerging pension gap through individual savings to an extent that at least offsets the reduction in public pensions. Since it was assumed that low-income households and households with children have the greatest difficulty in doing so, large tax credits are targeted to these households. A more modest tax deduction for contribution applies to everyone.

In this paper the focus is on public acceptance of the Riester pensions and their dynamics over time. Specifically, we want to highlight the distributional and cost aspects: for whom do the saving incentives work, i.e., who has joined the new subsidized pension scheme, how costly is the scheme, who pays for it, and who is likely to be able to fill the emerging pension income

\footnotetext{
${ }^{1}$ In essence, the formerly monolithic German pay-as-you-go system is transiting to a multi-pillar system with public, occupational and private pensions. For a detailed description of the pension reform process in Germany see Börsch-Supan and Wilke (2004). .
} 
gap. Finally, we investigate whether the new private pension plans displace saving for other purposes.

Riester pensions and their matching subsidies were introduced in a step-wise fashion from 2002 through 2008, allowing us to identify the effects of subsidies on uptake rates. We use the German SAVE data, a new panel data set on households' saving and asset choices, sociodemographic characteristics, and psychological determinants of saving and old-age provision behavior. Currently, the SAVE data capture the time period between 2001 and 2010 and offer a unique opportunity to investigate old-age provision based on very recent data with a broad set of explanatory variables.

The issues investigated in our paper contribute to the discussion about the impact of retirement saving incentives in various countries. In the U.S., Venti and Wise (1990) on the one side and Gale and Scholz (1994) on the other have sparked a very controversial discussion about the efficacy of Individual Retirement Accounts (IRAs) as saving devices; see Skinner and Hubbard (1996) for an early review. Disney et. al. (2001) have provided a helpful review tailored to the UK situation. These controversies have accompanied pension reform in almost all developed countries, generating an interest in cross-national analyses of retirement saving behavior under different tax and subsidy regimes, see Börsch-Supan (2003, 2004). This paper adds the recent German experience to this discussion and updates the paper by Börsch-Supan, Reil-Held and Schunk (2008).

The paper is structured around the themes of design, costs and the effectiveness of the new system. Section 2 and 3 are devoted to the interaction between design and first experiences in the process that led to the scheme as it is now: Section 2 describes the key initial design features of Riester pensions in Germany, and Section 3 documents the uptake of Riester pensions between 2001 and 2010 and the design adaptations contributing to the uptake dynamics. Section 4 summarizes the costs of the Riester scheme and the changes in retirement savings associated with them. Sections 5, 6 and 7 address the effectiveness of the scheme: Section 5 provides descriptive statistics on the dynamics of enrolment in Riester pension plans by socio-economic characteristics. Section 6 collects circumstantial evidence on the macroeconomic impact of Riester pensions, in particular whether they have crowded out other saving, and Section 7 shows how the pension income gap is likely to be filled, the ultimate aim of the scheme. Section 8 provides some concluding observations. 


\section{The initial design of Riester pensions}

While Riester pensions are voluntary, they are designed to fill the gap that will be created by the scheduled reduction of public pension benefits in response to the pressures of population aging. In order to achieve this goal, the German Retirement Savings Act $^{2}$ introduced a comprehensive regime of saving incentives for certified pension products that have become known as "Riester pensions". These new retirement saving arrangements are eligible to receive subsidies in two forms: a match of the participants contribution and the deduction of all contributions from income for tax purposes.. When initially established in 2001 the certification regulations and subsidy mechanisms were rather complex, however they were significantly simplified in 2005. In this section, we first describe the initial approach because it provides many lessons for effective subsidy design.

Criteria for "certifiable" products. Initially, private pension plans were eligible for subsidies if they fulfilled eleven criteria stipulated by the "Certification of Retirement Pension Contracts Act". These included, among others, the following requirements: savers must make regular contributions; product providers must guarantee that the nominal investment return in each calendar year be positive; benefits must be disbursed as certain types of lifelong annuities; lump sum payments at retirement must not exceed $20 \%$ of the accumulated wealth; administrative and marketing costs must be spread over at least ten years; and all providers must be registered with a supervisory board. Most Riester products were provided by the insurance industry, but also banks and investment funds offered Riester products, see Figure 2 below.

Eligibility. Not all households are eligible for the subsidies. The eligibility criteria are complex, although the simple intention was that everyone affected by the reduction in public pension benefits should be eligible for private pension subsidies. Hence, the group of eligible beneficiaries includes employees paying mandatory social insurance contributions; recipients of wage compensation benefits (such as unemployment benefit, child-raising benefits, etc.); self-employed people who are mandatory members of the public pension system; farmers; and tenured civil servants. Spouses of eligible individuals are also entitled to receive subsidies ("indirect entitlements") provided that they enroll in a separate pension plan of their own.

Subsidies. Due to government budget constraints, the generosity of the subsidy scheme was phased in starting in 2002 and ending in 2008, with a doubling the applicable parameters in each step. This is shown in Table 1. Column 1 shows the percentage of gross earnings which

\footnotetext{
${ }^{2}$ The law „Altersvermögensgesetz “ dates from 2001.
} 
must be contributed to the plan in order to qualify for the full subsidy. The full subsidy is displayed in columns 2-4 and has three elements. First, there is a basic subsidy (column 2) that is a match of the participants own contribution. This basic subsidy is means-tested for low and middle income households. Individuals eligible for this basic subsidy pay their savings into a certified pension plan and, in the initial design, had to file an application form to receive the subsidies each year. The plan provider receives the matching basic subsidy from the government and credits it to the account as part of the total contribution. Second, all eligible savers receive an additional subsidy for each child (column 3). Third, contributions to Riester pension plans can be tax deductable as special expenses up to a maximum amount (column 4). This amount has been fixed in nominal terms at $€ 2100$ from 2008 onwards which will, unless changed, eventually erode this third subsidy/incentive mechanism. ${ }^{3}$

Table 1: Statutory incentives for supplementary pension provision.

\begin{tabular}{lcccc}
\hline \hline & $\begin{array}{c}\text { Maximum contribution } \\
\text { [percentage of gross } \\
\text { earnings] }\end{array}$ & $\begin{array}{c}\text { Basic subsidy } \\
{[\epsilon \text { p. a.] }}\end{array}$ & $\begin{array}{c}\text { Child subsidy } \\
{[\epsilon \text { p. a.] }}\end{array}$ & $\begin{array}{c}\text { Maximum tax } \\
\text { deduction } \\
\text { [€ } \text { p. a.] }\end{array}$ \\
\hline 2002 & $(1)$ & $(2)$ & $(3)$ & $(4)$ \\
$2004 / 05$ & 1 & 38 & 46 & 525 \\
2006 & 2 & 76 & 92 & 1050 \\
2008 & 3 & 114 & 138 & 1575 \\
\hline \hline
\end{tabular}

Note: * The child subsidy is $€ 300$ for children born after 2007.

The matching contribution subsidy was reduced proportionally if contributions to the Riester plan are lower than the maximum indicated in column 1 . Since the subsidy itself is counted as part of that contribution, some mathematical skills are required to compute the exact contribution required to receive the full subsidy - another feature reducing the transparency of the design. Moreover, the minimum own contribution depended on the number of children and the year in which the individual had enrolled in the Riester plan.

The complexity of the design made the substantial size of the subsidies less apparent for many individuals. While low-income earners receive a relatively high subsidy due to the matching basic subsidy, higher earners accrued additional subsidies from the tax deductions due to the progressive nature of the income tax rates. This generates a slightly U-shape profile of subsidies as shown in Figure 1. Overall, the subsidies average about $45 \%$ of contributions,

\footnotetext{
${ }^{3}$ An automatic inflation adjustment was suggested for instance by the Commission for the Sustainable Financing of the German Social Security Systems (2004), of which one author was a member.
} 
varying between $24 \%$ and $90 \%$ depending on income and number of children. At the mean earnings (€42.000) the statutory subsidy rate is $39 \%$.

Figure 1: Subsidy as percentage of total (own plus government matching) contribution

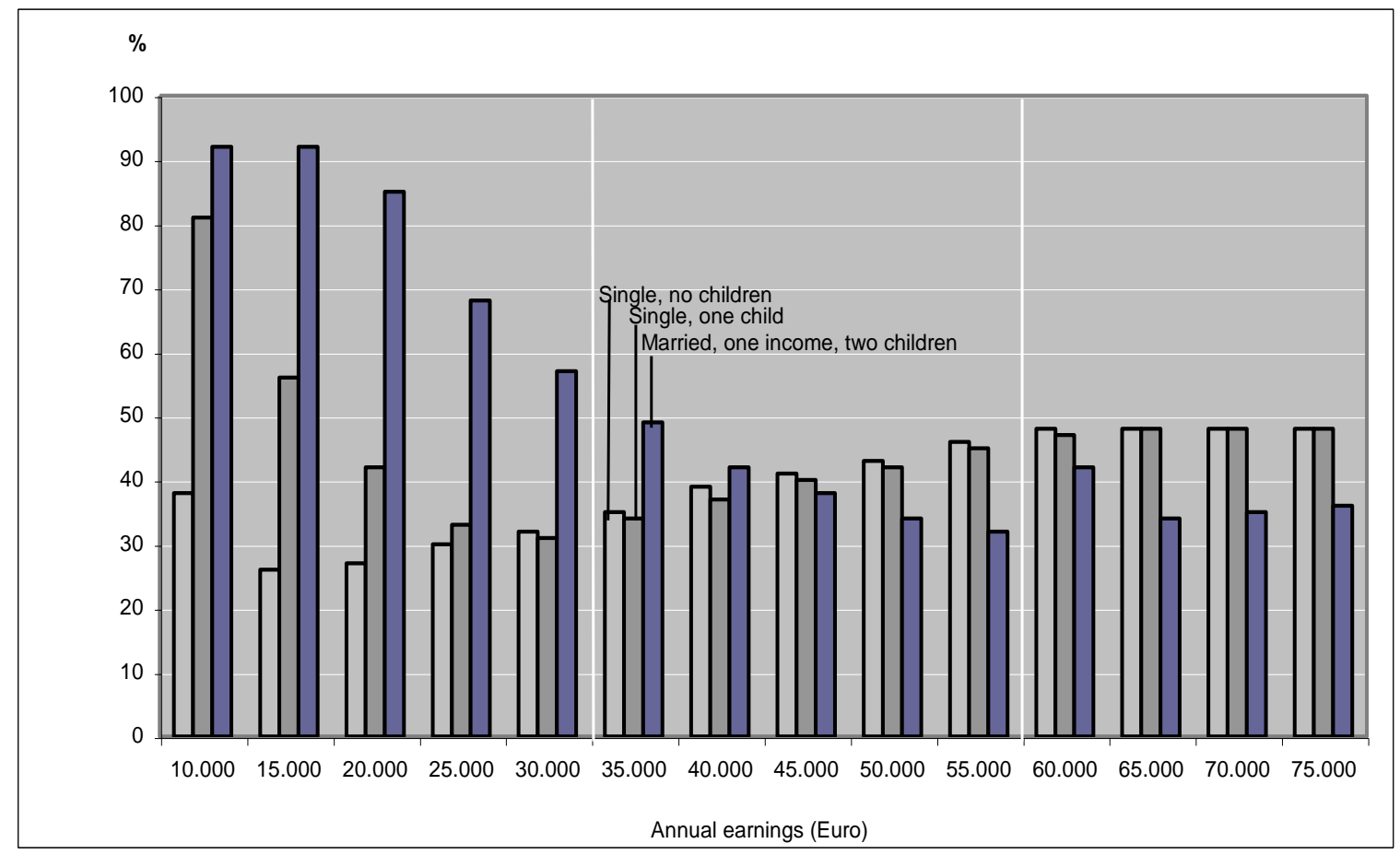

Note: Direct subsidy/the tax advantage as a percentage of savings in form of the new supplementary pensions. Source: Deutsche Bundesbank (2002).

Owner-occupied housing. While savings usually must be accumulated until retirement and are then disbursed in some type of annuity, there is an exception for owner-occupied housing. The 2001 law permitted withdrawals between $€ 10,000$ and $€ 50,000$ from the accumulated capital which had to be paid back into the pension plan in monthly installments latest by the age of 65 (if not, the subsidies received had to be paid back). The law was changed in 2008 and permitted withdrawals up to $100 \%$ of the accumulated capital to purchase owner-occupied housing without having to pay back the amount withdrawn. In addition, loan agreements ("Darlehensverträge") and building society saving contracts ("Bausparverträge") can be certified as Riester products receiving the subsidies described above. So far, such housingrelated products do not constitute a significant share of Riester products, see Figure 2.

\section{Uptake dynamics of "Riester pensions" and amended design}

Quarterly uptake figures are provided by the Federal Ministry for Labor and Social Affairs and are displayed in Figure 2. 
Figure 2: Development of Riester pensions (million contracts)

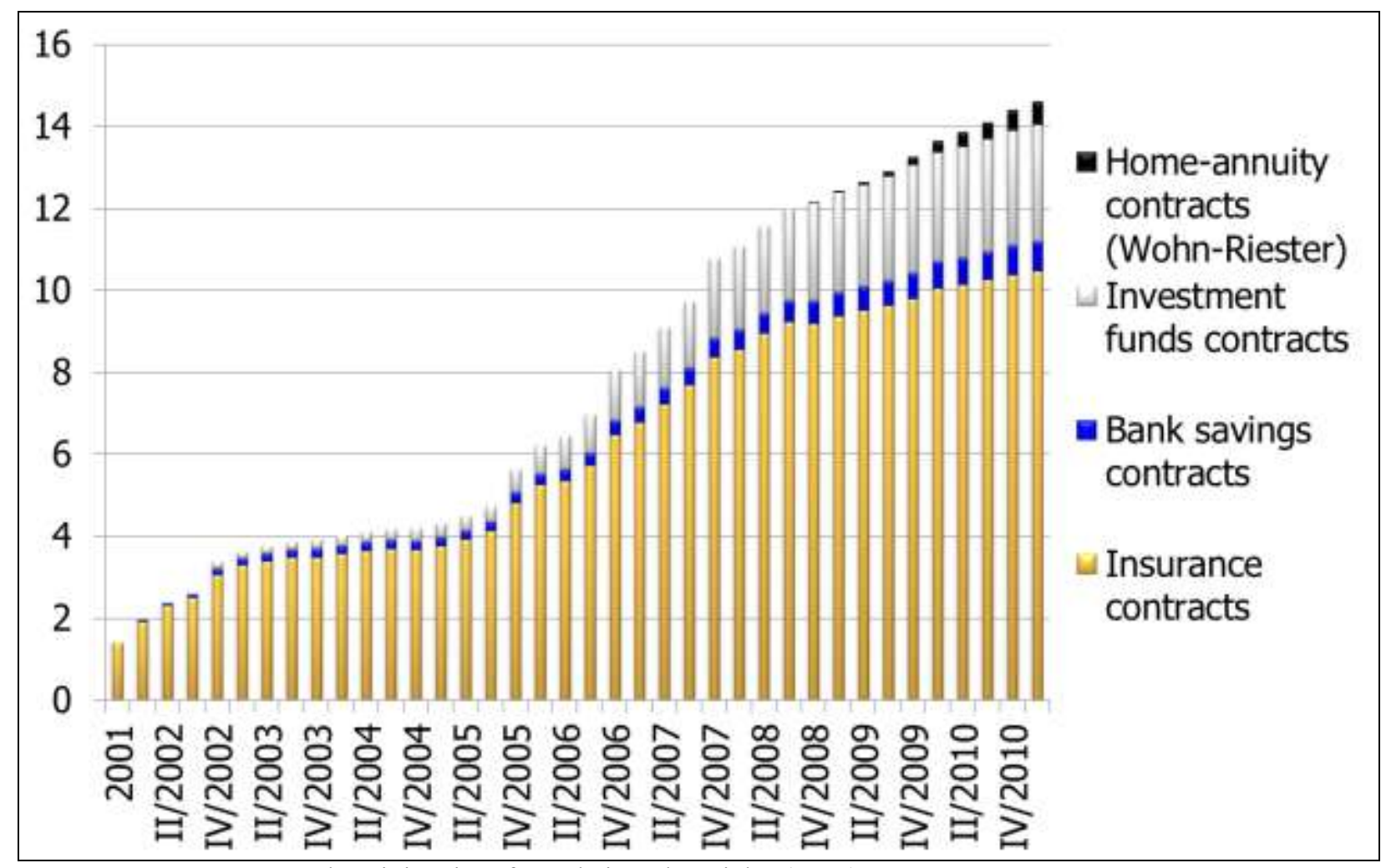

Source: Bundesministerium für Arbeit und Soziales (2011)

Around 1.4 million Riester pension plans were taken up in the first year after the introduction of incentives. ${ }^{4}$ After a period of initial enthusiasm, however, demand for Riester pensions flattened in 2003 and 2004. This lackluster growth and widespread criticism of the complex eligibility and subsidy design led to a simplification of the design in 2005 in an effort to improve acceptance of the new system by households and providers. The changes introduced in 2005 did not affect the subsidies described in Table 1 and Figure 1 but included:

1. The application procedure was simplified by replacing it with a one-off permanent subsidy application. Savers eligible for subsidies were allowed to authorize their pension provider to submit a subsidy application on their behalf every year.

2. The number of certification criteria was reduced from 11 to 5. Specifically, the share of Riester pensions to be annuitized was reduced from 80 to 70 percent; i.e., $30 \%$ of the accumulated capital could be received as a lump sum.

3. The participants minimum own contribution was standardized to $€ 60$ per annum.

\footnotetext{
${ }^{4}$ For an analysis of the initial phase see Dünn and Fasshauer (2003).
} 
4. Transparency of pension savings product and providers was improved. Information that was required to be provided about investment options, the structure of the portfolio and the risk parameters was extended. Providers were required to introduce a standardized calculation facilitating comparisons of alternative products.

5. Acquisition and marketing costs can now be spread over five rather than ten years; thereby selling Riester pensions became more attractive for providers. Although there were no formal limits for such charges, the certification process imposed some soft restrictions on charges which could be interpreted as usury.

6. These changes were accompanied by a modest government-sponsored public relations campaign; main advertizing efforts, however, were left to the providers of Riester products.

Demand for Riester pensions rose significantly in 2005 after these changes came into effect as shown in Figure 2. Around 900,000 new policies - around four times as many as during the whole of 2004 - were signed in the last quarter of 2005 alone. This upward trend continued throughout 2008. By the end of 2008, a total of more than 12 million pension plans eligible for subsidy support had been taken up. After 2008, the rate of increase flattened. This may have been the result of three causes: the maximum contribution rate was reached in 2008 as shown in Table 1; some socio-demographic strata may have reached saturation levels; and the financial crisis resulting in very low or negative returns may have discouraged new households from starting a Riester pension. While the increase in the number of contracts slowed down after 2008 the overall number of contracts has continued to increase at a linear rate in the ensuing period. At the end of 2009 , about $40 \%$ of the households potentially eligible for the subsidies held at least one Riester plan (Coppola and Gasche, 2011).

The dynamic development of the Riester Pensions occurred in parallel with the uptake of occupational pensions. It has ocurred, however, is in contrast to an essentially flat development of other unsubsidized private retirement savings arrangements as indicated in Figure 3. 
Figure 3: Coverage by private and occupational pensions

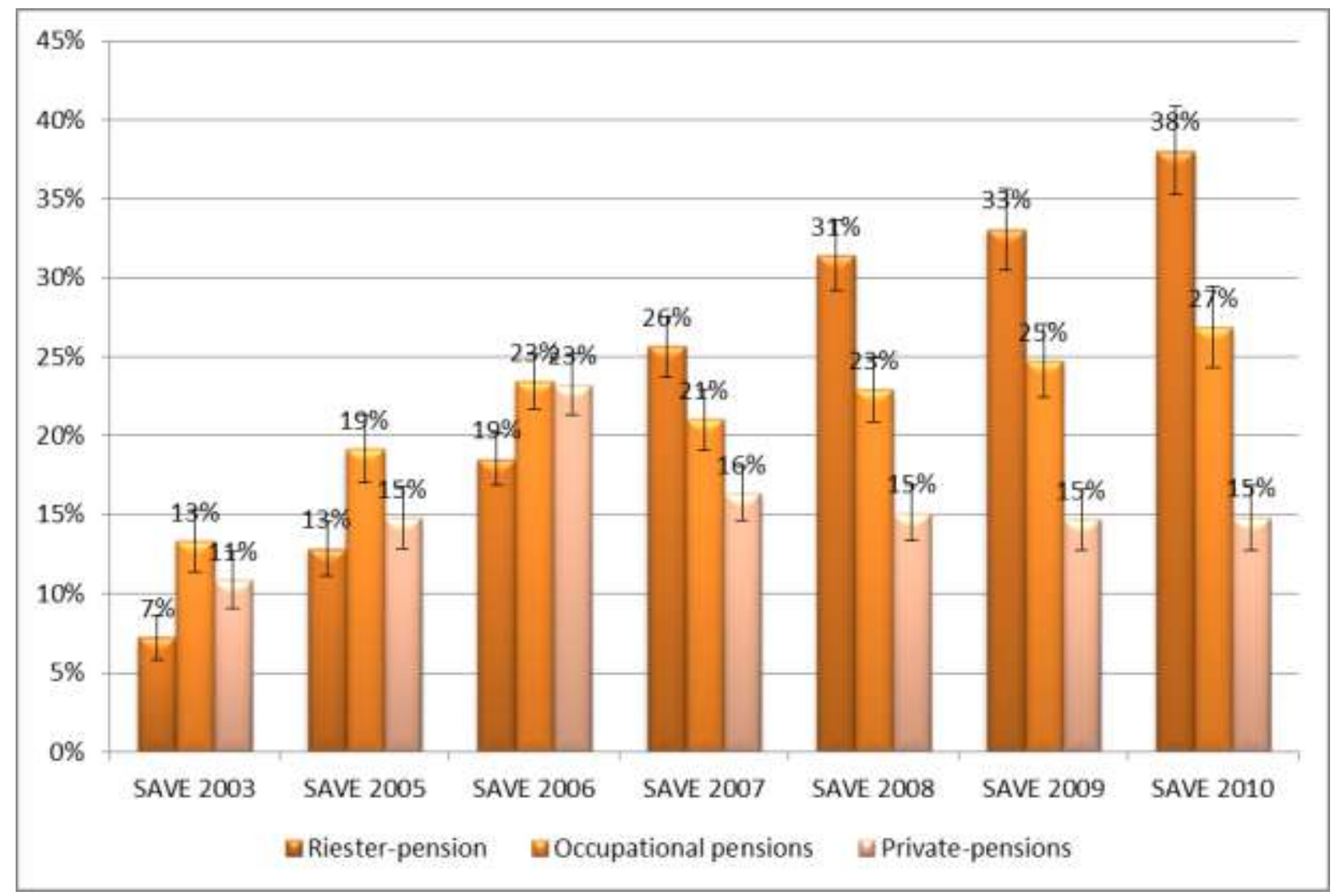

Source: Own calculations on the basis of the SAVE Panel.

In 2006, Riester pensions overtook occupational pensions as the main instrument for funded pension provision in Germany. Largely due to this development, the number of households with no private supplemental pensions decreased from $73 \%$ in 2001 to about $45 \%$ in 2009 , and about a quarter of households now have at least two saving instruments for their old-age provision as shown in Figure 4. 
Figure 4: Number of private and occupational pension instruments

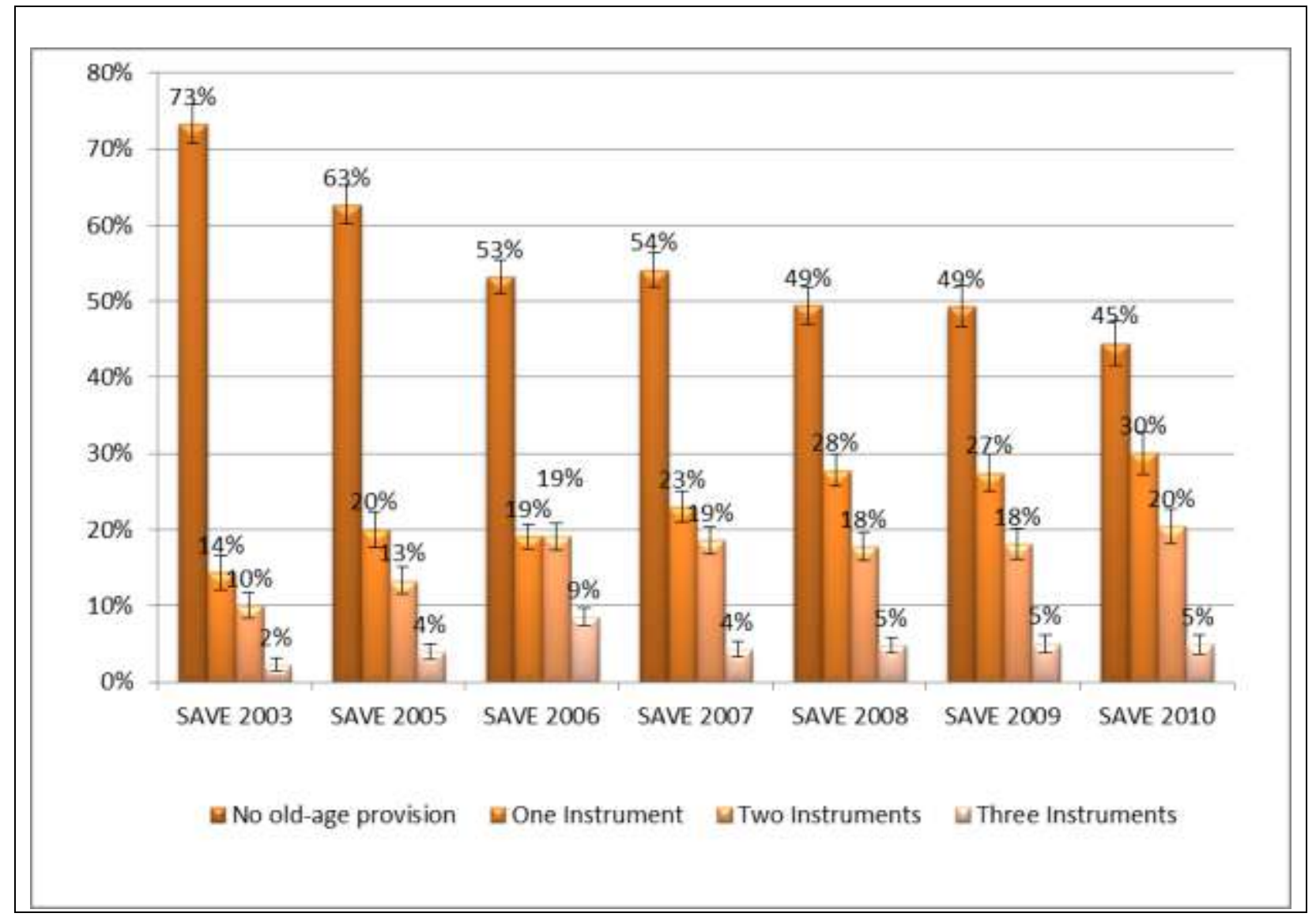

Source: Own calculations on the basis of the SAVE Panel.

\section{Fiscal costs and savings}

Riester pensions create direct fiscal costs in form of the means-tested basic and child subsidies that are shown in columns (2) and (3) of Table 1, and in form of foregone tax revenue that result from the exclusion of the allowable contribution levels displayed in the rightmost column of the table. Figure 5 shows the level and rate or increase in both of these elements of the fiscal costs from 2003 to 2010 when the total costs reached a level of $€ 3.5 \mathrm{bn}$, of which about $80 \%$ are attributable to the means-tested direct subsidies. In comparison, costs for public pension benefits (old age, disability and survivor pensions) were $€ 225 \mathrm{bn}$ in 2010. 
Figure 5: Fiscal costs of Riester pensions $(€ 1000)$

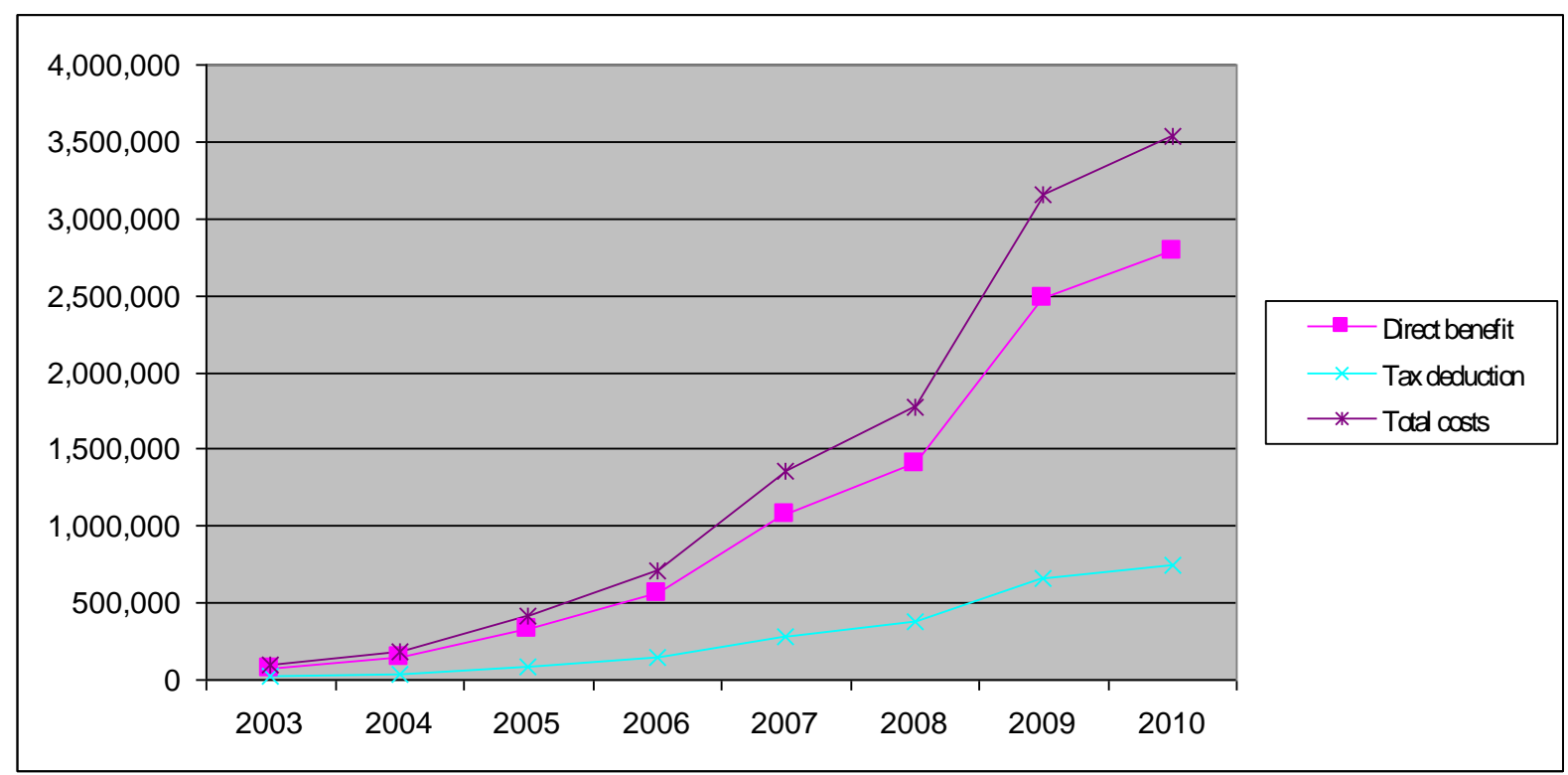

Source: Deutsche Rentenversicherung (2011), p. 76

The fiscal costs shown in Figure 5 are the actual payment of subsidies or foregone income tax revenue resulting from the new system. Since Riester subsidies can be claimed up to two years after paying into the account, and tax losses typically occur the year after income generation, it is not easy to match induced Riester saving in one year with the subsidies paid out in the same year. In addition to a potential mismatch between years, there are the deeper questions of causality and substitution which are addressed in Section 6.

Stolz and Rieckhoff (2008-2011) provide an attempt of such a matching, see Table 2. It does, however, only include the direct subsidies, not the tax deductions. Total savings in the accounts is composed of the matching subsidy and the own contribution by the individual on which the subsidy is calculated. Assuming that these overall savings would not have been made without the incentives of the subsidies, one Euro of subsidies (not including the value of the income tax exclusion) induced about additional 2.2 Euros saving for old age, see column (4) which might, under these strong assumptions, be interpreted as a measure of cost effectiveness of the subsidy design. 
Table 2: Direct subsidies and associated saving in Riester plans $(€ 1000)$

\begin{tabular}{lcccc}
\hline \hline & Direct subsidies & Total saving & Own contribution & Effectiveness \\
\hline 2005 & $(1)$ & $(2)$ & $(3)$ & $(4)$ \\
2006 & 521,917 & $1,762,749$ & $1,240,832$ & 2.4 \\
2007 & $1,134,339$ & $3,635,886$ & $2,501,547$ & 2.2 \\
2008 & $1,445,688$ & $4,834,565$ & $3,388,877$ & 2.3 \\
\hline \hline
\end{tabular}

Source: Stolz and Rieckhoff (2008-2011) based on ZfA data.

As noted above, Table 2 does not include additional saving which may have been induced by the tax deductability of Riester plan contributions. Another analysis, Gerber and Zwick (2010), links the data from the Central Subsidies Agency (ZfA) with income tax data in order to include the effects of tax deductions and compute a broader measure of subsidy rates that can be converted into a similar measure of cost effectiveness. Since the linkage solves some, but creates other time matching problems, the results are not fully comparable with Table 2 but yield a similar result of a "cost effectiveness" of 1.9 Euros of new savings for each Euro of subsidies across all households. It is substantially higher for households with children $(\mathrm{e}=2.4)$ than for childless households ( $\mathrm{e}=1.1)$.

\section{Targeting success}

Another dimension of program effectiveness is the ability of the subsidy design to reach the targeted population. Riester pensions were specifically designed to help low-income earners and families with children build up savings for retirement, a element of the German population in which saving rates are typically low. The Central Subsidies Agency provides quarterly uptake figures that are associated with a limited number of socio-economic characteristics. Analyses by Stolz and Rieckhoff (2008-2011) show that individuals with low labor incomes, women, families, and employees in the former East Germany are well represented among subsidy recipients.

These data, however, are based on subsidized individuals and not on households, and they do not reveal total household income, only those income components subject to means-testing. Our analysis on targeting therefore uses the SAVE data set, a panel study of saving behavior by

\footnotetext{
${ }^{5} 57.1 \%$ of beneficiaries were female and $42.9 \%$ male in the contribution year $2008.24 .4 \%$ of those receiving subsidies were from the new federal states in eastern Germany, 75.6\% from the former territory of West Germany. Around 9.8 million people received a basic subsidy and 3.7 million people an additional child's subsidy (Stolz and Rieckhoff, 2011).
} 
German households. Börsch-Supan et al. (2010) provide a detailed description of the SAVE dataset. It contains longitudinal data on households' saving and asset choices, sociodemographic characteristics, and psychosocial determinants of savings behavior, particularly related to old-age provision. ${ }^{6}$ Thus far, the panel has been surveyed in 2001, 2003, and then annually from 2005 through 2010. SAVE provides data at the level of the individual respondent and the respondent's spouse (referred to in the following as household). In 2006, the total sample size was about 3500 households. We restrict the analysis in this paper to those households who have not yet retired. ${ }^{7}$ All descriptive statistics are weighted based on the income and age distribution of the German Microcensus. ${ }^{8}$

Figure 6 shows the uptake of Riester pensions by categories of age. One would expect to find differences that are related to age because as a result of the recent reforms the replacement rate of the public pension system will slowly decline for future cohorts. Younger generations are thus more strongly affected than older generations. In addition younger generations have a longer period to accrue the subsidies of the new system and are more likely to have dependent children and thus be eligible for the higher level of subsidies. One would therefore anticipate higher participation rates among younger households relative to among older ones. This is indeed what Figure 6 indicates.

\footnotetext{
${ }^{6}$ Essig (2005) and Schunk (2006) provide further details. We are grateful to the German Science Foundation (DFG) for funding this data set.

${ }^{7}$ To be precise: the interview is conducted with the individual who knows best about the household's finances.

${ }^{8}$ As in all surveys that deal with sensitive topics such as household finances, item non-response to sensitive questions is not ignorable (see Essig and Winter (2003) and Schunk (2006) for discussion and documentation). To prevent biased inference based on an analysis of complete cases only, an iterative multiple imputation procedure has been applied to the SAVE data (Schunk, 2008). All results in this paper use the fully imputed SAVE data.
} 
Figure 6: Uptake of Riester pensions by age group

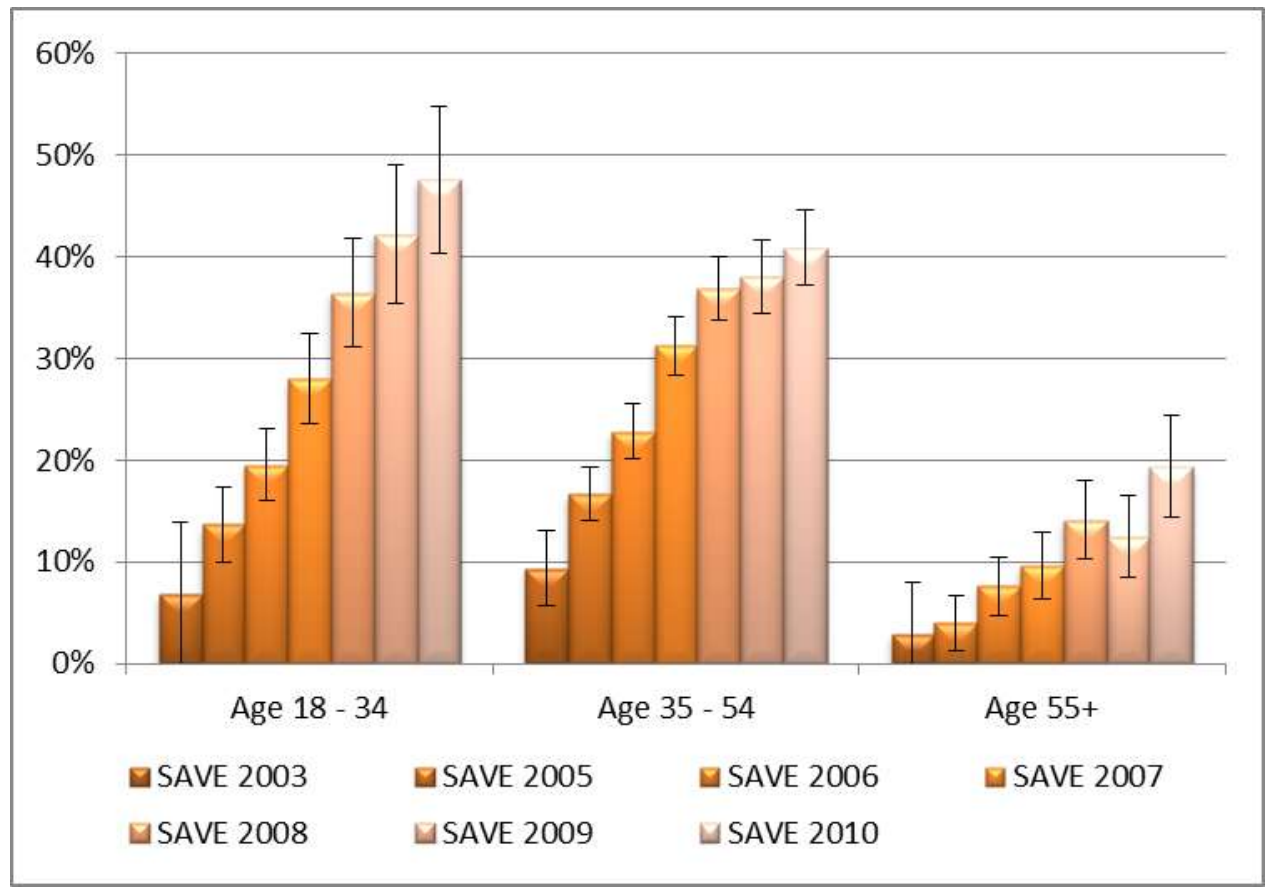

Source: Own calculations based on SAVE 2003-2010, households eligible for subsidies. Brackets show 95\% confidence intervals. Weighted figures.

Figure 7 shows the strong positive relationship between the number of children and the proportion of households with a Riester pension plan. The Riester subsidies increase linearly with the number of children so it is not surprising that there is strong demand for Riester products among parents with more than two children. 
Figure 7: Uptake of Riester pensions by number of children

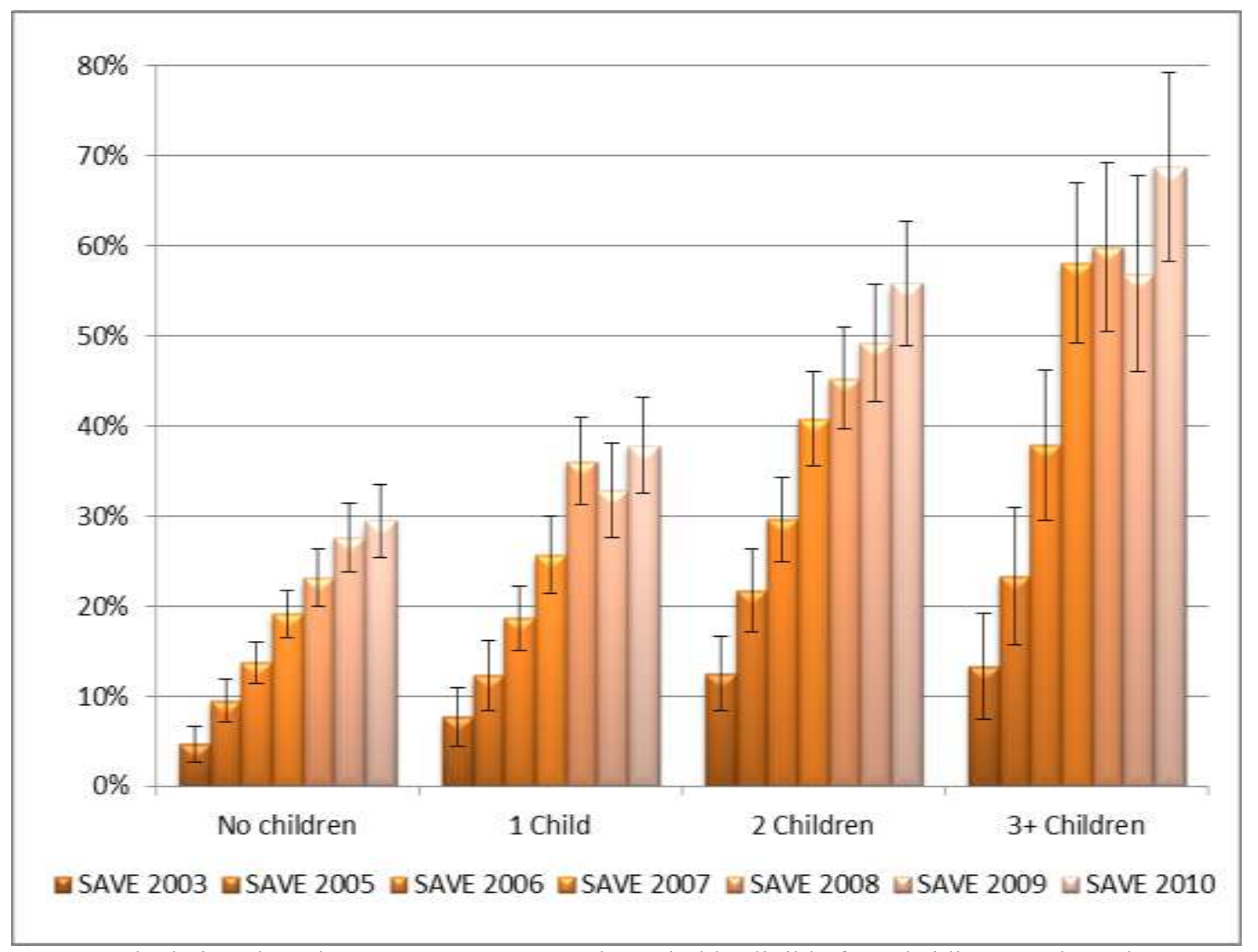

Source: Own calculations based on SAVE 2003-2010, households eligible for subsidies. Brackets show 95\% confidence intervals. Weighted figures.

About $60 \%$ of households with two or more children - more than twice as many as among childless households - had a Riester pension plan in 2010. Riester pension plans were proliferating most markedly among households with more than 3 children. Figure 8 provides significant evidence of the effectiveness of the system in enrolling families with children that can be attributed to the large child subsidy since there is no comparable development in the other private pension instruments: 
Figure 8: Private pension instruments by number of children in 2009

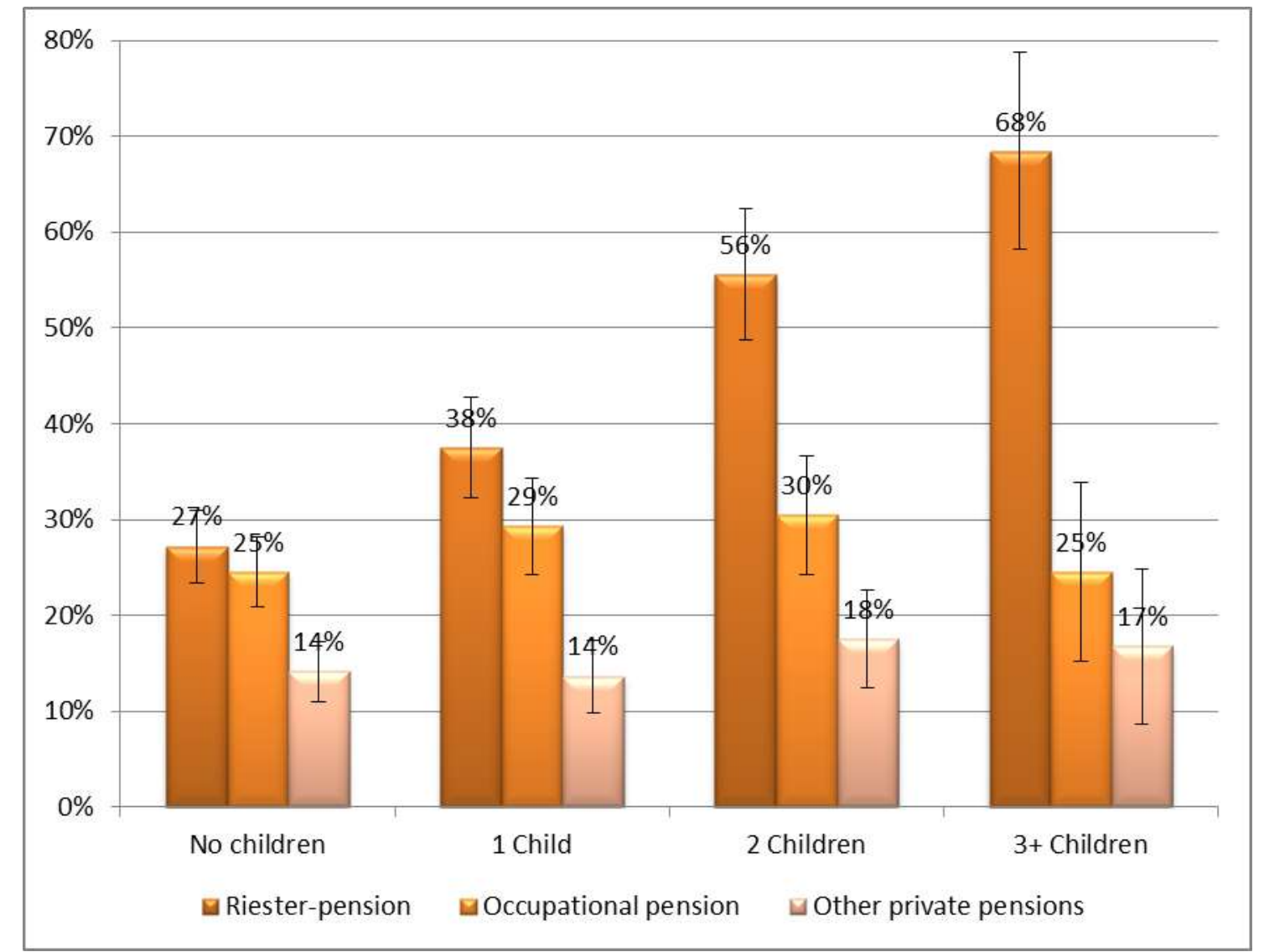

Source: Own calculations based on SAVE 2010, households eligible for subsidies. Brackets show $95 \%$ confidence intervals. Weighted figures.

Reaching low-income households however has proven to be more difficult than eliciting participation by families with children. Figure 9 shows that the proportion of households holding private pension instruments increases with growing disposable household income. This pattern is most apparent for occupational pensions. Only around 19\% of households in the lowest income bracket have taken up Riester pension plans, while almost a half of those in the two upper income brackets indicate participation in the system. However, given the substantial challenges in reaching low income groups for any type of retirement savings some success of the system can be found in the fact that among low-income households, Riester pensions are much more frequent than any other form of private pension provision. As a result, Riester pensions are more equally distributed by income than occupational pensions or unsubsidized private pension schemes.

All income groups have exhibited an increasing demand for supplemental pensions since 2002 as shown in Figure 10. Starting from an already lower initial level, the increase in percentage points is least apparent in the lowest income bracket. This effect is less pronounced when expressed in relative percentage terms. Particularly striking is the impressive growth of 
occupational pensions and unsubsidized private pension instruments among high income households.

Figure 9: Private pensions by monthly household disposable income in 2009

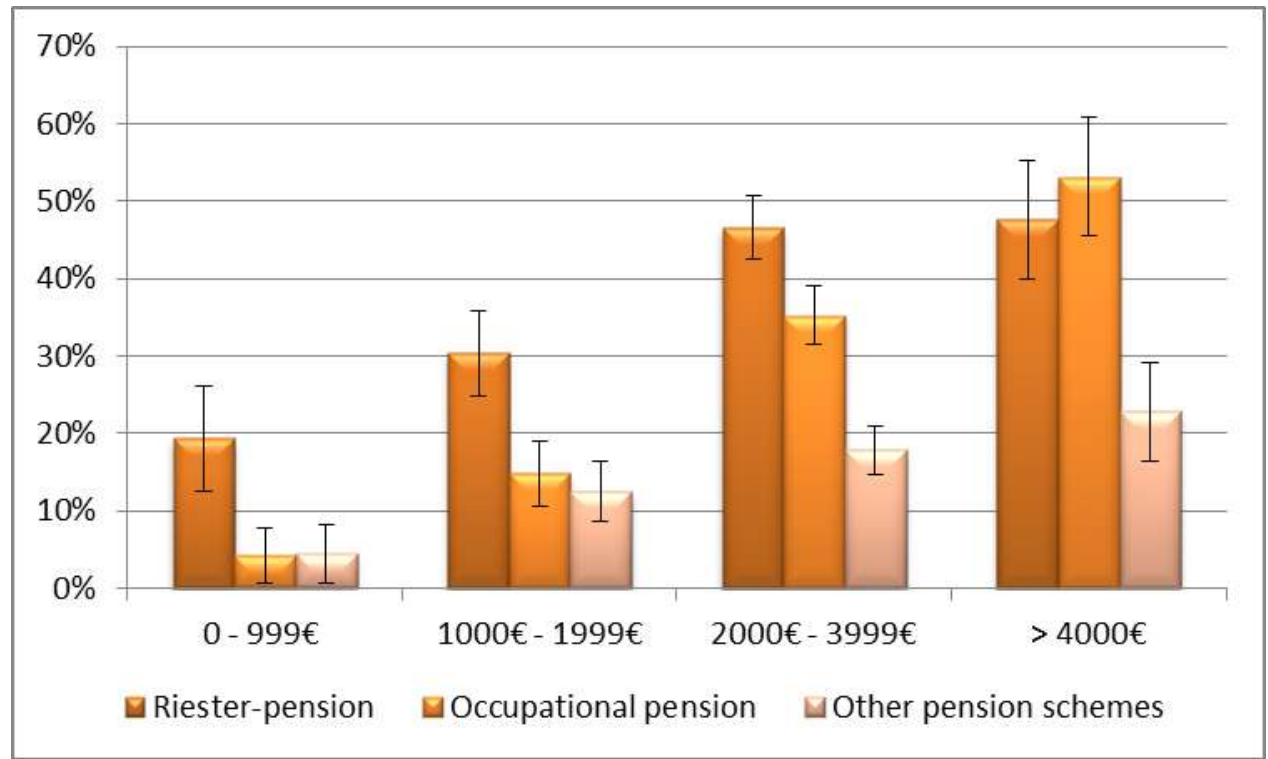

Source: Own calculations based on SAVE 2001-2010, households eligible for subsidies. Brackets show 95\% confidence intervals. Weighted figures. 
Figure 10: Uptake of Riester pensions by quintiles of monthly household disposable income

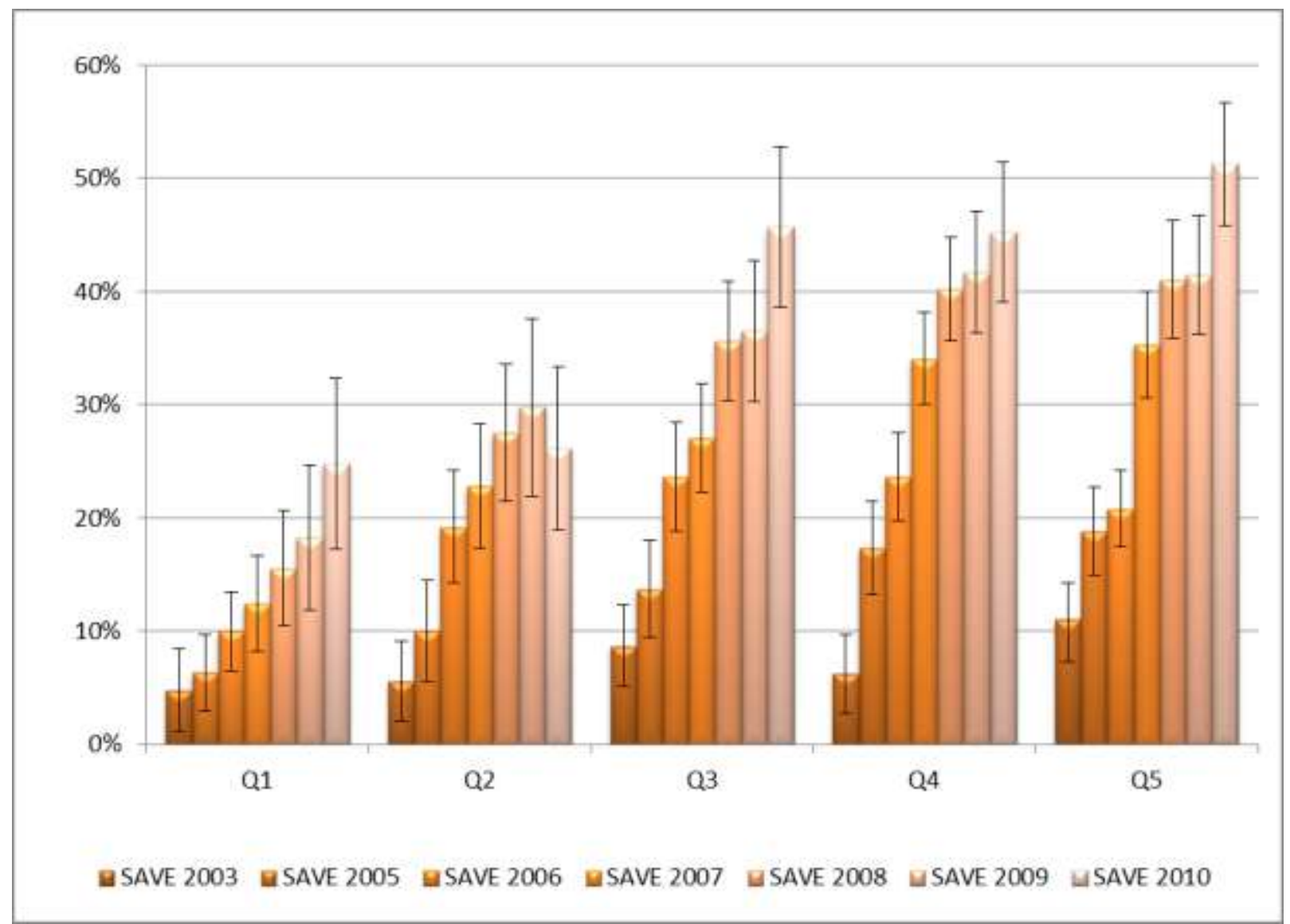

Source: Own calculations based on SAVE 2001-2010, households eligible for subsidies. Brackets show 95\% confidence intervals. Weighted figures.

An important result from Figure 10 is the unbroken increase in the share of households with Riester pension plans in the lowest income quintile since 2002. Low income earners actually have a slightly higher percentage rate of increase in their uptake than the middle of the income distribution. Hence, the jury is still out with regard to how well Riester pensions will actually end up serving low-income households.

\section{Displacement effects or crowding in?}

As the earlier discussion of fiscal costs shows, Riester pensions are an expensive government program.. The subsidies increase direct government spending and thus potentially reduce aggregate national saving. In addition, the successful uptake of Riester pensions may have simply displaced other saving, in particular saving within other types of private funded pensions. The macroeconomic effect of subsidizing Riester pensions may thus be zero or even negative. 
The papers by Corneo, Keese and Schröder (2009, 2010) and Pfarr and Schneider $(2010,2011)$ provide econometric analyses which cannot refute the hypothesis that subsidizing Riester pensions only produces displacement effects. Both papers, however, take strong implicit assumptions in order to overcome the problem of a missing counterfactual (due to the design of the Riester scheme, virtually everybody is eligible, so there is no natural control group to compare with), e.g., that having a Riester pension and having other savings are independent decisions.

Also we cannot provide an analysis which unambiguously isolates the causal effect of the subsidies on total saving since most households are eligible, making cross-sectional analysis difficult as ineligible households (e.g. certain groups of self-employed) have quite different socio-economic characteristics. Comparisons over time are more credible however similarly a clean counterfactual is not available. Evidence is thus more circumstantial than causal.

One way to address the issue is to ask households directly about the extent that the subsidies stimulate new savings. Responses to these types of questions have been analysed by Coppola and Reil-Held (2010). Responses to questions about changes in behavior may be subjective and contain elements of wishful thinking or ex-post justification. Nevertheless, the results shown in Figure 11 are rather unambiguous: only a minority of households says that they saved less in total since starting to be enrolled in a Riester pension plan; most households respond that they have saved more. Particularly striking is that a very large proportion of low-income households indicated that they had saved more. The two upper quintiles of income provided similar patterns of responses. 
Figure 11: Change in total saving after being enrolled in a Riester plan

\section{Since the subscription of the Riester-contract we are...}

Household's income quintiles
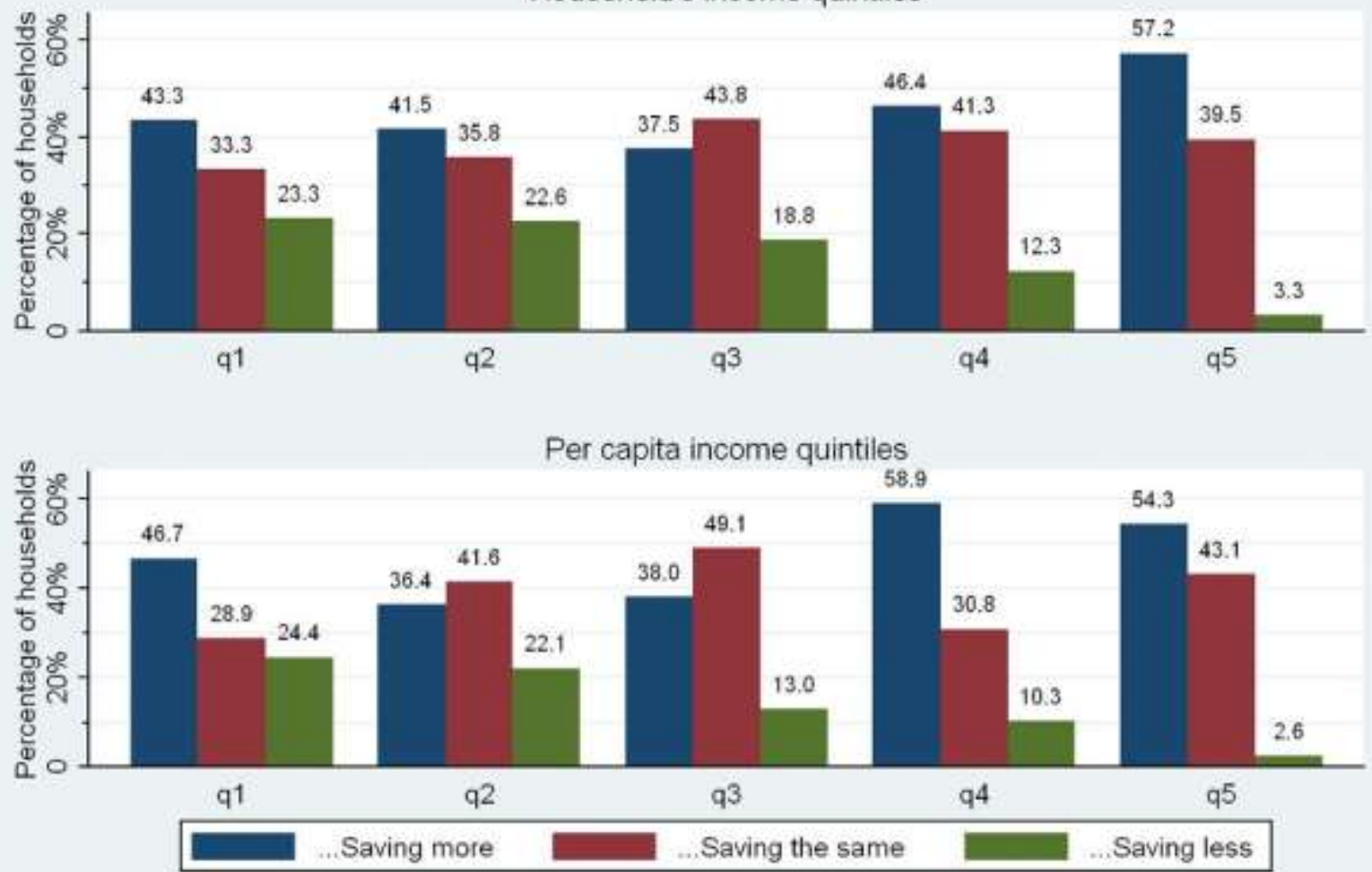

Source: Coppola and Reil-Held (2010) based on SAVE 2008, households with a Riester pension, weighted data.

As a less subjective piece of evidence, Figure 3 has shown that the increase of Riester pensions was not accompanied by a decline in the prevalence of other pension instruments: over the time period of their introduction occupational pensions also increased and unsubsidized pension plans stayed essentially flat between 2004 and 2009. It is also noteworthy that the aggregate household saving rate did not decline in the decade during which Riester pensions were introduced, increasing from 9.4 percent of disposable income in 2001 to 11,4 percent in 2010. The new pensions did not result in an increase in a rise in aggregate dis-saving either. Until the financial crisis and its large-scale fiscal stimulus packages, government deficits declined.

Börsch-Supan, Reil-Held and Schunk (2007) provide an econometric analysis of supplemental pensions, taking account of many socio-economic variables. They provide evidence on displacement effects via two channels. First, they employ a bivariate regression model, in which the decision to take up a subsidized Riester pension plan and the decision to enroll in other unsubsidized private pension plans are modeled simultaneously. A negative correlation between the two equations would indicate displacement. Second, they include competing 
motives for saving as explanatory variables. A negative coefficient on such variables would also indicate displacement.

Table 3 presents selected results of two specifications. Specification A describes disposable income as a set of four quintile indicators. Specification B employs a quadratic function of disposable income. In both specifications, the first dependent variable, shown in columns 1 and 3, indicates whether a household has a Riester pension plan, while the second dependent variable, shown in columns 2 and 4, indicates whether a household has an unsubsidized private pension plan. All variables refer to the end of year 2005 .

Table 3: Selected determinants of the demand for Riester and other private pension products (bivariate probit estimates)

\begin{tabular}{|c|c|c|c|c|}
\hline \multirow[b]{2}{*}{ Variable } & \multicolumn{2}{|c|}{ Specification A } & \multicolumn{2}{|c|}{ Specification B } \\
\hline & Riester & $\begin{array}{c}\text { Other private } \\
\text { pensions }\end{array}$ & Riester & $\begin{array}{c}\begin{array}{c}\text { Other private } \\
\text { pensions }\end{array} \\
\end{array}$ \\
\hline & (1) & $(2)$ & (3) & $(4)$ \\
\hline \multicolumn{5}{|l|}{ Saving motives: } \\
\hline Intention to buy real estate & $\begin{array}{l}0.001 \\
(0.01)\end{array}$ & $\begin{array}{l}0.143 \\
(1.67)^{*}\end{array}$ & $\begin{array}{l}-0.001 \\
(0.01)\end{array}$ & $\begin{array}{l}0.147 \\
(1.71)^{*}\end{array}$ \\
\hline Reason for saving: Buy real estate & $\begin{array}{l}-0.090 \\
(2.11)^{*}\end{array}$ & $\begin{array}{l}-0.057 \\
(1.39)\end{array}$ & $\begin{array}{l}-0.089 \\
(2.08)^{* *}\end{array}$ & $\begin{array}{l}-0.058 \\
(1.43)\end{array}$ \\
\hline Reason for saving: Provide for unforeseen events & $\begin{array}{l}-0.096 \\
(1.44)\end{array}$ & $\begin{array}{l}-0.057 \\
(0.86)\end{array}$ & $\begin{array}{l}-0.086 \\
(1.28)\end{array}$ & $\begin{array}{l}-0.052 \\
(0.79)\end{array}$ \\
\hline Reason for saving: Pay off debts & $\begin{array}{l}-0.055 \\
(1.24)\end{array}$ & $\begin{array}{l}-0.041 \\
(0.99)\end{array}$ & $\begin{array}{l}-0.054 \\
(1.22)\end{array}$ & $\begin{array}{l}-0.043 \\
(1.03)\end{array}$ \\
\hline Reason for saving: Old-age provision & $\begin{array}{l}0.229 \\
(3.06)^{* * *}\end{array}$ & $\begin{array}{l}0.694 \\
(7.87)^{* * *}\end{array}$ & $\begin{array}{l}0.218 \\
(2.92)^{* * *}\end{array}$ & $\begin{array}{l}0.691 \\
(7.86)^{* * *}\end{array}$ \\
\hline Reason for saving: Holiday & $\begin{array}{l}0.009 \\
(0.18)\end{array}$ & $\begin{array}{l}-0.068 \\
(1.49)\end{array}$ & $\begin{array}{l}0.012 \\
(0.25)\end{array}$ & $\begin{array}{l}-0.069 \\
(1.51)\end{array}$ \\
\hline Reason for saving: Finance major purchases & $\begin{array}{l}0.042 \\
(0.81)\end{array}$ & $\begin{array}{l}0.039 \\
(0.77)\end{array}$ & $\begin{array}{l}0.035 \\
(0.68)\end{array}$ & $\begin{array}{l}0.037 \\
(0.72)\end{array}$ \\
\hline Reason for saving: Finance (grand)child education & $\begin{array}{l}-0.038 \\
(0.81)\end{array}$ & $\begin{array}{l}-0.091 \\
(2.02)^{* *}\end{array}$ & $\begin{array}{l}-0.038 \\
(0.80)\end{array}$ & $\begin{array}{l}-0.094 \\
(2.09)^{* *}\end{array}$ \\
\hline Reason for saving: Inheritance & $\begin{array}{l}-0.124 \\
(2.32)^{* *}\end{array}$ & $\begin{array}{l}0.090 \\
(1.80)^{*}\end{array}$ & $\begin{array}{l}-0.128 \\
(2.39)^{* *}\end{array}$ & $\begin{array}{l}0.090 \\
(1.80)^{*}\end{array}$ \\
\hline Reason for saving: State subsidies & $\begin{array}{l}0.264 \\
(6.03)^{* * *}\end{array}$ & $\begin{array}{l}-0.015 \\
(0.38)\end{array}$ & $\begin{array}{l}0.269 \\
(6.13)^{* * * *}\end{array}$ & $\begin{array}{l}0.008 \\
(0.20)\end{array}$ \\
\hline $\begin{array}{l}\text { Alternative instruments: } \\
\text { Other form of suppl. pension provision (dummy) }\end{array}$ & $\begin{array}{l}0.469 \\
(6.27)^{* * *}\end{array}$ & $\begin{array}{l}0.462 \\
(6.56)^{* * *}\end{array}$ & $\begin{array}{l}0.466 \\
(6.25)^{* * *}\end{array}$ & $\begin{array}{l}0.466 \\
(6.64)^{* * *}\end{array}$ \\
\hline $\begin{array}{l}\text { Mc-Fadden } \mathrm{R}^{2} \\
\text { Rho }\left[\mathrm{Chi}^{2}(1)\right] \\
\text { Number of observations }\end{array}$ & $\begin{array}{r}0.13 \\
0.05 \\
22\end{array}$ & $\begin{array}{l} \\
{[1.32]} \\
55\end{array}$ & $\begin{array}{r}0.136 \\
0.060 \\
22\end{array}$ & $\begin{array}{l}{[1.54]} \\
55\end{array}$ \\
\hline
\end{tabular}

Note: Absolute value of the $\mathrm{z}$ statistics in parentheses. Regression also includes a large set of socio-economic control variables. $*$ significant at $10 \%$ confidence interval, ** significant at $5 \%$, *** significant at $1 \%$ Source: Börsch-Supan, Reil-Held und Schunk (2008). 
The regressions have a very satisfactory fit, here measured as McFadden's R-squared, see the lower part of Table 3. Moreover, the estimated model exhibits a positive correlation between the two equations, or, more precisely, between the unobservables in the decision to take up a subsidized Riester pension plan and the decision to enroll in unsubsidized private pension plans. While the correlation is small and not statistically significant, it does not support the hypothesis of a crowding out between Riester and unsubsidized private pension plans.

Table 3 shows a set of variables in the regression which reflect the importance of different saving motives for respondents. We are specifically interested in three saving motives: the acquisition of real estate, the wish to bequeath wealth, and pocketing state subsidies. First, there is evidence pointing to a possible displacement effect between old-age provision and real estate purchase. This is apparent when looking at households who report a particular interest in saving for the purchase of real estate property. The more important this savings motive is, the less likely respondents have taken up a Riester pension plan. A second significantly negative coefficient is attached to the variable indicating a wish to save for a bequest. Our interpretation is that the requirement for Riester plans to be paid out as an annuity acts as a disincentive for households for whom making a bequest is an important saving motive.

In addition to Riester pension plans and unsubsidized private pension plans, occupational pension plans and whole life insurance products have been very popular as instruments to provide supplemental retirement income. ${ }^{9}$ The coefficient of a variable indicating the presence of such instruments is statistically significant and positive: households which are already covered by one of these alternative pension types are more likely to have a Riester pension plan. One interpretation is that households who think ahead and invest in old-age provision at all tend to use several instruments for this purpose. As opposed to saving for real estate acquisition or saving for bequests, where we found substitution, this result is consistent with a form of "crowding in" among pension products.

\section{Filling the pension gap}

The ultimate measure of success is the extent to which Riester pensions will fill the "pension gap" created by the reduction of benefits provided by the pay-as-you-go financed public pension system. Börsch-Supan and Gasche (2010) simulate pension payments from the public system and pension payments from a Riester annuity for a typical employee saving exactly the amounts required to obtain the maximum subsidy according to Table 4. Figure 12 shows the

\footnotetext{
${ }^{9}$ See German Federal Ministry for Labor and Social Affairs (2006)
} 
policy-induced decline in public pension benefits and the increasing annuity from Riester savings.

Figure 12: Benefits from public and Riester pensions ( $\%$ of average earnings)

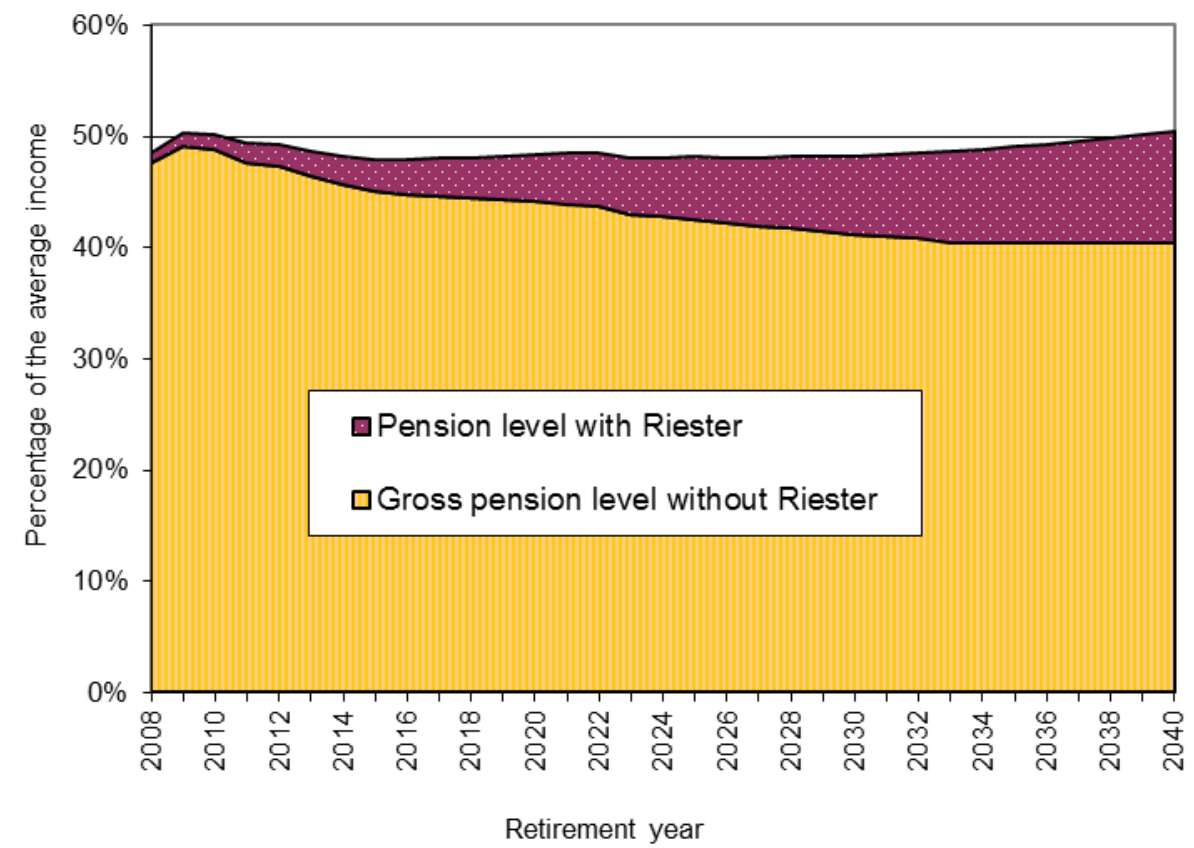

Source: Börsch-Supan and Gasche (2010).

Individuals retiring in 2008 had accumulated very little Riester savings since the program started only in 2002. Individuals retiring later have an increasing time span to accumulate Riester savings until an equilibrium will be reached in about 2047.

Although the combined pension benefits will be larger than the current public pension benefits from about 2030 onwards, Figure 13 shows that the transitional generation will not be able to fill the pension gap completely. 
Figure 13: Filling the pension gap ( $\%$ of average earnings)

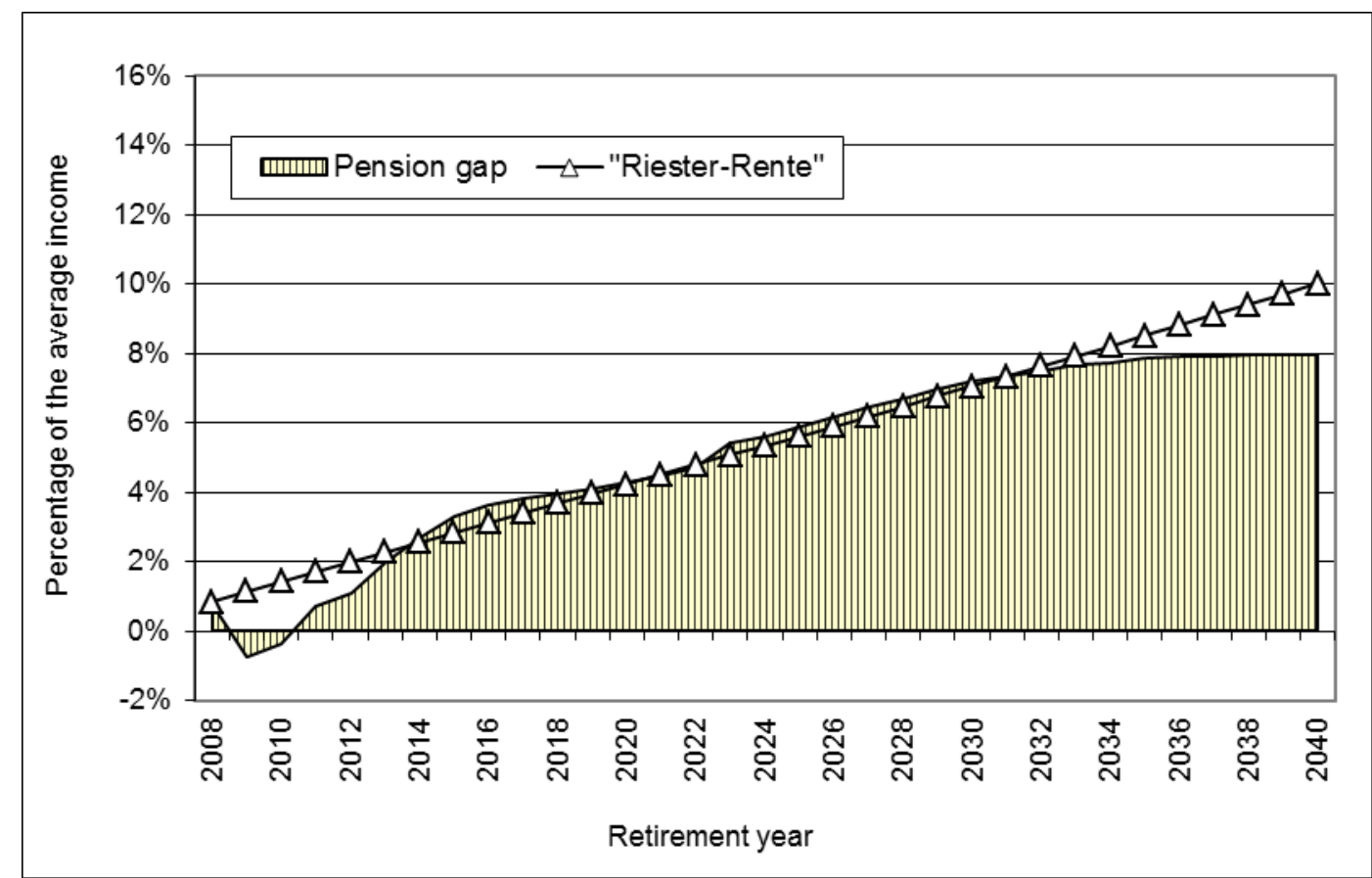

Source: Börsch-Supan and Gasche (2010).

Actual saving for old age may be less than suggested by Table 1 since uptake is well below $100 \%$, individuals may not save the full amount, or may interrupt contributions due to factors such as unemployment or other episodes of financial distress. It may also be larger than the rates suggested by Table 1 since individuals may have other old-age saving plans such as unsubsidized individual account pension plans or occupational pensions.

Börsch-Supan, Essig and Wilke (2005) provide a simulation exercise based on actual household data that sheds some light on this issue. They measure current financial wealth and the current financial net saving rate for all households in the SAVE panel. Assuming constant net saving rates and a real return of $2.8 \%$, they compute financial wealth at retirement, and convert it into a real annuity. This annuity is then compared to the pension gap.

On average, Germans have more than closed the emerging pension gap. More than two thirds will be able to fill the gap between what they would have received in retirement income under the old and new public systems. The coverage rate for this gap, (Riester annuity divided by pension gap), is $120 \%$ for the average household. The distribution, however, is quite skewed. Predictably, results are very different with respect to socio-economic characteristics, especially income. While the median household will still be able to compensate for the the cuts in public pensions, about $27 \%$ of the households represented by the SAVE panel will not be able to fill the pension gap. 


\section{Conclusions}

The most obvious lesson from the Riester pensions experience is that new forms of subsidized savings need time before they are able to really take off. It took over ten years in the U.S. before Individual Retirement Accounts (IRAs) were accepted by households in the upper 60 percent of the income distribution (Venti and Wise, 1990). In Germany, the Riester pension plans have exhibited a more rapid and dynamic growth. Growth in the first few years was very steep, then stalled, but rebounded after the 2005 legislative changes and continued through the financial crisis. Overall, growth rates are much higher than those experienced in the U.S. One reason maybe the direct subsidies, another the urgency of offsetting the benefits reductions in the wake of the public pension reforms.

There are several explanations for the discontinuous development of Riester pensions. Poor product design is likely the cause for the initially lower rates of acceptance.. Moreover, the learning process regarding the need and way to invest in old-age provision took time, despite heavy advertising. As people learn from their social environment, the pace of this development depends on how widespread such pensions are in the population at large ("critical mass", Ruprecht 2004), generating exponential growth until saturation is reached.

We cannot exactly identify whether the dynamic spread of Riester pensions is due to the financial incentives, the availability of information, or the marketing efforts made by government and providers, mainly insurance companies. However, it is striking that the acceleration in Riester saving only kicked in after substantial simplifications had been made to the scheme. Therefore, an important second lesson is to avoid complex savings plans which are not immediately understood by customers. Further simplifications are possible without jeopardizing the aims of the program (e.g., see Westerheide et al., 2010).

The target groups of the Riester reform in 2001 were mainly families with children and individuals with low income. Among those, parents with more than one child seem to be the group that was most easily reached. The evidence is less compelling for the other target group, low-income households. While the trend increase is still unbroken, the level of uptake remains low with just $25 \%$ in the lowest income quintile engaged in the system. A key lesson derived from this is that high subsidies alone are not enough to reach low income households: information and social acceptance appears to be a crucial element in reaching this group. Coppola and Gasche (2011) find that the level of knowledge about the eligibility for the Riester subsidies is directly related with the household's income: households in the bottom quintile of 
the income distribution have a higher probability to wrongly believe that they are not eligible for the subsidies than households in the upper quintiles.

This insight is strengthened by the regression results of Börsch-Supan,. Reil-Held and Schunk (2008) and Coppola and Reil-Held (2010): Households with higher levels of educational attainment are, holding other characteristics like income and family size constant, more likely to enroll in Riester pensions than households with financial respondents who have not completed any vocational training. This is consistent with the broader experience indicating that knowing future pension replacement levels correlates positively with enrolling in private pension schemes. A fourth lesson, therefore, is that information and the knowledge about arrangements relating to old-age pension provision are vital to achieving high take up rates.

While the SAVE data does not allow for a cleanly designed experiment, they provide circumstantial evidence about possible displacement effects. First, households who desire to purchase residential real estate are significantly less likely to have a Riester pension plan. The clumsy withdrawal rules of the Riester regulations clearly do not provide these households with sufficient liquidity in order to persuade them to make provision for old age alongside with saving to acquire real estate property. We find similar evidence that stated bequest motives displace Riester pension plans with their strict annuity rules. This however does not necessarily indicate that these restrictions should be alleviated. On the contrary, they are needed since Riester pensions are designed to fill the gap in public pension benefits after pension reform, and these pay-as-you-go pensions are paid out as a life-long annuity.

The desire to purchase property and the wish to bequeath assets are saving motives which appear to compete with taking up Riester pensions. Occupational pensions and whole life insurance, however, are found to be complements rather than substitutes. This provides an important fifth lesson. One interpretation is that households which think ahead and invest in old-age provision tend to use several instruments for this purpose. In this sense, there are "crowding in" effects of fostering retirement saving. While the subsidization of Riester pensions are an expensive program, the net effect (i.e., additional savings created after subtracting subsidies and reductions in other saving vehicles) appears to be clearly positive.

Sixth and finally, the ultimate measure of success is the extent to which Riester pensions will fill the "pension gap" created by the reduction of benefits provided by the pay-as-you-go financed public pension system. While, on average, Germans will be able to more than close the evolving pension gap, the distribution is quite skewed. While the median household will 
still be able to compensate for the cuts in public pensions, about $27 \%$ of German households will not be able to fill the pension gap.

Riester pensions have produced some interesting achievements although clearly they are not a panacea to fully solve the challenges of adequate retirement income levels. While preventing poverty in old age requires different instruments, this new pension instrument can be regarded a success story for the middle of the income distribution in Germany. It has moved about $€ 9.4 \mathrm{bn}$ from consumption and/or other saving instruments not related to old-age provision into savings sepecifically earmarked for old-age and has thus made the overall system of retirement income more robust and stable. At the same, it has reduced the pressure on the younger generations by permitting lower pay-as-you-go contribution rates compared to the pre-reform situation. Whether this justifies the Riester scheme's tax and subsidy costs of $€ 3.5 \mathrm{bn}$, equal to 1.5 percent of the total pay-as-you-go pension budget, is a judgment call. 


\section{References}

Boeri, T., A. Börsch-Supan and G. Tabellini (2002): Would You Like to Reform the Pension System? The Opinions of European Citizens, American Economic Review 92: 396-401.

Börsch-Supan, A. (Ed.) (2003): Life-Cycle Savings and Public Policy: A Cross-National Study of Six Countries. Academic Press, London.

Börsch-Supan, A. (2004): Mind the Gap Incentives: The Effectiveness of Incentives to boost Retirement Savings in Europe. OECD Economic Studies 39: 111-144.

Börsch-Supan, A. and L. Essig (2005): Household saving in Germany: Results of the first SAVE study, in D. A. Wise (Ed.), Analyses in the Economics of Aging, 317-352, The University of Chicago Press, Chicago.

Börsch-Supan, A., D. Schunk and A. Reil-Held (2007): The Savings Behaviour of German households: First Experiences with state-promoted Private Pensions. Mea-Discussion Paper 136-07. MEA - Mannheim Research Institute for the Economics of Aging, University of Mannheim.

Börsch-Supan, A., M. Coppola, A. Eymann, L. Essig and D. Schunk (2010): The German SAVE Study. Design and Results. MEA Study No. 6, MEA - Mannheim Research Institute for the Economics of Aging, University of Mannheim.

Börsch-Supan, A., and M. Gasche (2010): Kann die Riester-Rente die Rentenlücke in der gesetzlichen Rente schließen? Diskussionspapier Mai 2010, Mannheim Research Institute for the Economics of Aging, Mannheim University.

Bundesministerium für Arbeit and Soziales (2006): Renten- und Alterssicherungsbericht 2005, http://www.bmas.de, Berlin.

Commission for the Sustainable Financing of the German Social Security System (2004): Bericht der Kommission, German Federal Ministry for Health and Social Affairs, Berlin.

Coppola, M. and A. Reil-Held (2010): Jenseits staatlicher Alterssicherung: die neue regulierte private Vorsorge in Deutschland, in: Lutz Leisering (ed.), Die Alten der Welt. Neue Wege der Alterssicherung im globalen Norden und Süden, Campus, Frankfurt

Coppola, M. and M. Gasche (2011): Die Riester-Förderung - das unbekannte Wesen, Diskussionspapier Mai 2011, Mannheim Research Institute for the Economics of Aging, Mannheim University.

Corneo, G., M. Keese and C. Schröder (2009): The Riester Scheme and Private Savings: An Empirical Analysis Based on the German SOEP, Schmollers Jahrbuch 129 (2), 321332.

Corneo, G., M. Keese and C. Schröder (2010): The Effect of Saving Subsidies on Household Saving - Evidence from Germany, Ruhr Economic Papers, No. 170

Deutsche Bundesbank (2002): Funded old-age provision and the financial markets. Monthly Report July 2002: 25-39, Frankfurt.

Disney, R., C. Emmerson and M. Wakefield (2001): Pension reform and saving in Britain, Oxford Review of Economic Policy, Vol. 17(1), 70-94.

Dünn, S. and S. Fasshauer (2003). Ein Jahr Riesterrente - Eine Übersicht aus Sicht der gesetzlichen Rentenversicherung. Deutsche Rentenversicherung 1-2. 
Essig, L. (2005): Methodological aspects of the SAVE data set, Mea-Discussion-Paper 80-05, MEA - Mannheim Research Institute for the Economics of Aging, University of Mannheim.

Essig, L. and J. Winter (2003): Item nonresponse to financial questions in household surveys: An experimental study of interviewer and mode effects. Mea-Discussion Paper 39-03. MEA - Mannheim Research Institute for the Economics of Aging, University of Mannheim.

Gale W.J. and J.K. Scholz (1994): IRAs and household saving, American Economic Review, $84,1233-1260$

Gerber, U. and M. Zwick (2010): Daten zur kapitalgedeckten Altersvorsorge - die Riesterrente, Deutsche Rentenversicherung, Heft 2/2010, S. 197 - 207

German Federal Ministry for Health and Social Security (2005): National Strategy Report on Old-Age Pension Provision, http://www.bmas.band.de/BMAS/Redaktion/Pdf/ Publikationen/national-strategy-report-on-old-age-pension-provision.

Hoynes, H., M. Hurd and H. Chand (1998): Household Wealth of the Elderly under Alternative Imputation Procedures, in: D. A. Wise (Ed.), Inquiries in the Economics of Aging, 229257, The University of Chicago Press, Chicago.

Kennickell, A. B. (1998): Multiple Imputation in the Survey of Consumer Finances, Proceedings of the 1998 Joint Statistical Meetings, Dallas TX.

Kriete-Dodds, S. and D. Vorgrimler (2007): Staatliche Förderung der Riester-Rente für das Jahr 2002, Wirtschaft and Statistik 3/2007.

Lang, O. (2000): Steueranreize and Geldanlage im Lebenszyklus : empirische Analysen zu Spar- and Portfolioentscheidungen deutscher Privathaushalte. Baden-Baden : NomosVerlags-Gesellschaft.

Lusardi, A. (1999): Information, Expectations, and Savings for Retirement. In: Henry Aaron (Ed.), Behavioral Dimensions of Retirement Economics, Washington, D.C.: Brookings Institution Press and Russell Sage Foundation, 1999, 81-115.

Lusardi, A. and O. Mitchell (2006): Financial Literacy and Planning: Implications for Retirement Wellbeing. Wharton School Discussion Paper, University of Pennsylvania.

Madrian, B. and D. Shea (2001): The Power of Suggestion: Inertia in 401(k) Participation and Savings Behavior. Quarterly Journal of Economics. 116(4): 1149-1187.

Pfarr, C. and U. Schneider (2010): Angebotsinduzierung und Mitnahmeeffekt im Rahmen der Riester-Rente: eine empirische Analyse, SOEPpapers on Multidisciplinary Panel Data Research $n^{\circ} 341$.

Pfarr, C. and U. Schneider (2011): Anreizeffekte und Angebotsinduzierung im Rahmen der Riester-Rente: Eine empirische Analyse geschlechts- und sozialisationsbedingter Unterschiede, Perspektiven der Wirtschaftspolitik 2011 12(1): 27-46

Ruprecht, W. (2004): Automatische Entgeltumwandlung in der betrieblichen Altersversorgung - eine Replik, Wirtschaftsdienst 10: 651-656.

Skinner, J. und R.G. Hubbard (1996), Assessing the Effectiveness of Saving Incentives, Journal of Economic Perspectives 10(4), 73-90.

Schunk, D. (2006): The German SAVE Survey: Documentation and Methodology. MEADiscussion-Paper 109-06. MEA - Mannheim Research Institute for the Economics of Aging. University of Mannheim. 
Schunk, D. (2008): A Markov Chain Monte Carlo Algorithm for Multiple Imputation in Large Surveys. Advances in Statistical Analysis, 92, 1, 101-114.

Schunk, D. and J. Winter (2007): The relationship between risk attitudes and heuristics in search tasks: A laboratory experiment. Münchener Wirtschaftswissenschaftliche Beiträge (VWL) 2007-9.

Sommer, Mathias (2007): Fiskalische Auswirkungen einer Erweiterung des Förderrahmens von Riesterrenten, MEA Discussion Paper 122-07, University of Mannheim.

Stolz, U. and C. Rieckhoff (2005): Aktuelle Ergebnisse der zulagengeförderten Altersvorsorge, Die AngestelltenVersicherung 9/05, 409-416.

Stolz, U. and C. Rieckhoff (2006): Zulagenzahlungen der zentralen Zulagestelle für Altersvermögen - Auswertungen für das Beitragsjahr 2003, RV-aktuell 08/06, 306-313.

Stolz, U. and Rieckhoff, C. (2008): Förderung der zusätzlichen Altersvorsorge für das Beitragsjahr 2005 durch die ZfA, RVaktuell 9/2008.

Stolz, U. and Rieckhoff, C. (2009): Beitragsjahr 2006: Erstmals mehr als eine Milliarde Euro Zulagenförderung durch die ZfA, RVaktuell 10/2009.

Stolz, U. and Rieckhoff, C. (2010): Beitragsjahr 2007: Zulagenförderung nochmals um mehr als ein Viertel gestiegen, RVaktuell 11/2010.

Stolz, U. and Rieckhoff, C. (2011): Förderung der Riester-Rente für das Beitragsjahr 2008 Mehr als neun Millionen Personen mit Zulagen, RVaktuell 12/2011.

Venti S. and D. Wise (1990), Have IRAs increased U.S. Savings? Evidence from consumer expenditure surveys, Quarterly Journal of Economics, 105, 661-98.

Westerheide, P., M.Feigl, L.Jaroszek, J.Leinert and A.Tiffe (2010): Transparenz von privaten Riester- und Basisrentenprodukten, Abschlussbericht zu Projekt Nr. 7/09, Zentrum für Europäische Wirtschaftsforschung, Mannheim. 